\title{
Overconfidence: Technical Analysis in Trading, Investment or Gambling?
}

Sri Utami Ady ${ }^{1}$, Alvy Mulyaningtyas ${ }^{2}$, Ilya Farida ${ }^{3}$

sri.utami@unitomo.ac.id ${ }^{1}$, alvy.mulyaning@unitomo.ac.id², ilyafarida221@gmail.com ${ }^{3}$

Universitas Dr. Soetomo, Indonesia ${ }^{1,2,3}$

\begin{abstract}
The purpose of this study is to understand and explore the overconfidence behavior of individual investors trading stocks. Overconfidence is the overconfidence of investors' behavior in analyzing stocks that causes various mistakes in decision making depending on the type of technology or analytical method used by investors in various types of trading. The method used in this study is a qualitative method with interpretive phenomenological design, informant search with indepth interview method and analytical method with phenomenological method from Moustakas. The results showed that all informants in this study experienced overconfidence in their respective conditions. Especially for day trading. Overconfidence will cause overtrading by only using technical analysis using charts and charts, which ultimately results in speculative behavior that leads to gambling or gambling. which is prohibited in Islam and is no longer an investment. The limitation of this research is the lack of types of investor scalpers that have not been obtained by researchers. The implication of this research is that the techniques or methods used in investment decision making determine the success of investing.
\end{abstract}

Keywords: overconfidence, qualitative, Fenomenology, investor behavior.

\section{Pendahuluan}

Pasar modal adalah wadah untuk mempertemukan pihak-pihak yang memiliki kelebihan dana dan pihak-pihak yang memiliki kekurangan dana. Adanya pasar modal yang efektif, efisien dan stabil akan sangat diperlukan oleh pelaku pasar modal, baik bagi investor yang menanamkan dananya di pasar modal, perusahaan yang terdaftar untuk kelangsungan harga saham mereka di masa depan, dan broker sebagai perantara perdagangan yang memperlancar perdagangan di antara pelaku pasar.

Pemerintah sebagai regulator melalui berbagai instansi yang terkait di dalamnya, meliputi Bursa Efek Indonesia, Otoritas Jasa Keuangan (OJK), Lembaga Kliring dan Penjaminan (KPEI) dan Lembaga Penyimpanan dan Penyelesaian (KSEI) memiliki otoritas untuk dapat menciptakan sistem perdagangan yang teratur, wajar, dan efisien serta melindungi kepentingan pemodal dan masyarakat [1].

Teratur berarti menjamin bahwa seluruh pelaku pasar modal wajib mengikuti ketentuan yang berlaku sesuai dengan bidangnya masing-masing dan melaksanakannya secara konsisten. Wajar berarti seluruh pelaku pasar modal melakukan kegiatannya dengan memperhatikan standar dan etika yang berlaku di dunia bisnis serta mengutamakan kepentingan masyarakat banyak [2]. Efisien berarti kegiatan pasar modal dilakukan secara cepat dan tepat dengan biaya yang relatif murah dengan pelaku pasar yang bertransaksi secara rasional.

Pada fenomena yang terjadi di lapangan, perdagangan yang dilakukan oleh pelaku pasar modal (investor) lebih banyak dipenuhi oleh aspek psikologis, [3]. Transaksi yang dilakukan oleh investor lebih banyak berdasarkan ikut-ikutan investor lain bahkan lebih banyak mengikuti 
perilaku investor asing (herding) [4]; [5], transaksi berdasarkan rumor (noise trading) karena kurangnya rasa percaya diri mereka terhadap kemampuan analisis pasar, melakukan overtrading (terlalu banyak perdagangan) yang justru merugikan mereka sendiri, oleh sebab itu peningkatan harga saham yang terjadi bukan berdasarkan aspek fundamental yang memang kuat, tetapi lebih banyak karena psikologi pasar, sehingga banyak perilaku spekulasi yang merugikan pasar modal secara keseluruhan [3][6]. Perilaku ini dapat menyebabkan ketidakstabilan pasar modal, bahkan dapat menimbulkan resesi ekonomi yang berkepanjangan jika tidak segera dibenahi meskipun fundamental ekonomi Indonesia sedang dalam kondisi bagus.

Krisis ekonomi yang terjadi pada tahun 1998 adalah sebuah contoh nyata, krisis yang terjadi di Indonesia, utamanya di pasar modal karena perilaku sebagian besar investor pasar modal yang hanya mengikuti perilaku investor asing (perilaku herding) tanpa adanya rasa percaya diri dan analisis yang mendalam dalam bertransaksi di pasar modal sehingga terjadi penjualan saham besar-besaran dari investor lokal karena mengikuti perilaku investor asing meskipun secara fundamental perusahaan-perusahaan di Indonesia dalam kondisi yang sangat sehat.

Salah satu perilaku bias para investor adalah overconvidence [3]. Overconvidence adalah perilaku terlalu percaya diri investor dalam bertransaksi/berinvestasi saham yang menyebabkan dia mengambil resiko yang tinggi tanpa disadari. Pompian, (2006) mendefinisikan overconfidence sebagai keyakinan yang tidak berdasarkan pada intuisi, penyesuaian, ataupun kemampuan kognitif sesorang. Overconfidence akan menyebabkan investor overestimate terhadap kemampuannya dalam mengevaluasi perusahaan sebagai investasi potensial, cenderung untuk melakukan overtrading dan underestimate terhadap risiko[8];[9]. Overtrading adalah perilaku investor yang melakukan trading berlebihan dan pada umumnya hanya dengan menggunakan Analisis teknis, menggunakan grafik harga saham historis, bahkan menggunakan sistem robotik, sehingga cenderung berpotensi judi dibandingkan berinvestasi.

[3] menunjukkan bahwa overconvidence dapat membuat investor melakukan investasi yang berisiko tanpa dia sadari, memegang portofolio yang buruk dan melepaskan saham-saham pemenang. [10] menunjukkan adanya overconfidence pada forecaster pasar saham di pasar keuangan di Jerman. Penelitian ini juga menunjukkan bahwa pengalaman berhasil di masa lalu meningkatkan level overconfidence.

Penelitian ini berusaha memotret perilaku overconvidence dan menggali pemahaman investor tentang perilaku mereka dalam berinvetasi. Pengertian gambling dan spekulasi sering disamakan, tetapi ada perbedaan mendasar antara keduanya yang terletak pada penguasaan teknik dan pengetahuan seseorang berkaitan dengan suatu tindakan, [11]. Seseorang yang berjudi (gambling) cenderung melakukan tindakannya tanpa analisis, karena memang tidak memiliki teknik dan pengetahuan yang memadai. Sebaliknya, spekulasi masih melibatkan analisis, bahkan kadang-kadang melibatkan informasi yang lengkap dan data yang akurat, meskipun keduanya sama-sama bertujuan untuk mencari keuntungan dalam jangka pendek. [12] meninjau hubungan konseptual antara gambling, spekulasi dan investasi. Hasil penelitian ini menunjukkan gambling berbeda dengan investasi pada banyak atribut dan harus dilihat sebagai konsep yang berbeda. Di sisi lain, spekulasi secara konseptual berada diantara gambling dan investasi. Secara empiris, penjudi, investor, dan spekulan memiliki kesamaan atribut kognitif, motivasi, dan kepribadian, dengan hubungan sangat kuat untuk gambling dan spekulasi. Atribut yang digunakan untuk membedakan adalah : 1) Aktivitas dan instrument, 2) jangka waktu, 3) tingkat risiko, 4) Expected return positif atau negatif, 5) peran peluang versus keahlian, 6) pembelian aset, 7) taruhannya, 8) peristiwa definitif dan hasil definitif, 9) utilitas ekonomi. 


\section{Overconvidence}

Overconvidence adalah keyakinan yang tidak berdasarkan pada intuitisi, penyesuaian, ataupun kemampuan kognitif seseorang. Konsep dari overconvidence diturunkan dari eksperimen psikologi kognitif dan survey dimana seseorang overestimate tentang kemampuan prediksinya dan kebenaran informasi yang dipunyai. Seseorang cenderung sulit untuk mengestimasi kemungkinan kejadian yang pasti terjadi, kurang dari 100\%. Artinya orang berpikir bahwa mereka lebih pintar dan memiliki informasi yang lebih baik daripada yang sebenarnya (Pompian, 2006; Daniel et al. dalam Thaler, 2005).

Konsekuensi dari overconvidence adalah Investor akan overestimate kemampuan untuk mengevaluasi perusahaan sebagai investasi yang potensial, sehingga menjadi buta terhadap informasi negatif yang mengindikasikan sinyal peringatan bahwa pembelian saham telah salah atau saham yang baru saja dibeli harus segera dijual.

Investor overconvidence cenderung untuk melakukan perdagangan yang berlebihan (overtrading) sebagai hasil dari keyakinan bahwa pengetahuan yang dimiliki lebih baik dibandingkan orang lain. Perdagangan yang berlebihan merupakan pendorong dihasilkannya return yang buruk sepanjang waktu karena overtrading dilakukan oleh investor mendasarkan kepada analisis teknis dengan memprediksi apakah harga saham beberapa menit atau jam ke depan, naik atau turun. Ketika investor memprediksi harga saham akan meningkat, dilakukan pembelian dan ketika harga akan menurun, saham dijual. Trading dilakukan dalam jangka waktu hari, jam, menit bahkan sampai detik, sehingga teknik ini dapat diibaratkan sebagai taruhan.

Investor overconvidence, karena ketidaktahuan, ketidakmengertian, dan ketidakpeduliannya terhadap kinerja investasi historik perusahaan, dapat underestimate terhadap risiko, sehingga dapat menghasilkan portofolio yang tak dapat mengekspektasi kinerja buruk, memegang portofolio yang tidak terdiversifikasi dengan baik sehingga cenderung menerima risiko yang lebih dari tingkat toleransi. [14] menunjukkan adanya keterkaitan antara overconfidence dan personality. Penelitian ini juga menunjukkan indikasi bahwa faktor-faktor personality trait dalam behavioral finance meliputi risktaking propensity, negative emotion, extraversion, masculinity, preference for innovation, conscientiousness, agreeableness and femininity.

\section{Metode}

\section{Phenomenology sebagai Metode untuk Memahami Perilaku Overconfidence}

Paradigma yang tepat untuk memahami dan mengeksplorasi perilaku bias investor adalah paradigma interpretif. Paradigma interpretif lebih menekankan pada makna dan interpretasi simbol seseorang [15]. Tujuan penelitian dalam paradigma ini adalah untuk memahami dan mengeksplorasi untuk kemudian menafsirkan makna, bukan untuk menjelaskan dan memprediksi hubungan seperti dalam penelitian kuantitatif. Secara umum, penelitian kualitatif bertujuan memahami fenomena yang dialami, mengapa ia mengalaminya dan bagaimana ia mengalaminya

\section{Situs, Informan dan Pengumpulan Data}

Situs penelitian adalah investor individu yang memperdagangkan saham di Bursa Efek Indonesia. Alasan pemilihan situs adalah investor individual yang memperdagangkan saham dengan perdagangan online sehingga pergolakan emosional akan dirasakan oleh investor itu sendiri. Penelitian yang menggunakan perilaku investor individu sebagai informan dalam studi 
non-positivistik relatif sedikit, dan ada sedikit penelitian yang mengeksplorasi perilaku bias overconfidence pada investor individu. Pencarian informan dilakukan dengan menggunakan metode sine qua non yang memilih informan dengan melihat kualifikasi yang telah ditentukan. Informan adalah investor aktif yang telah berinvestasi dalam saham selama minimal 5 tahun dan bukan bagian dari perusahaan (insider). Wawancara mendalam dilakukan di tempat yang disetujui oleh informan dalam jangka waktu tiga bulan. Proses pengumpulan data secara interaktif, dengan durasi 1 hingga 2 jam tergantung kondisi saat wawancara. Untuk mendapatkan informan kunci yang memenuhi kriteria, para peneliti memperoleh informasi dari Bursa Efek Indonesia. Selanjutnya, pencarian informan dilakukan dengan menggunakan teknik bola salju. (snowball). Wawancara mendalam dilakukan tiga hingga lima kali wawancara mendalam hingga mencapai jenuh tergantung pada subjektivitas peneliti dan masalah penelitian yang ingin mereka selidiki [16]; [17]; [18]. Penelitian kualitatif itu tidak dimaksudkan untuk menarik kesimpulan secara umum, tetapi untuk mengeksplorasi pengalaman tiap-tiap informan yang unik sehingga pentingnya penelitian kualitatif bukan ukuran sampel, tetapi kedalaman dan keunikan persepsi dan pengalaman setiap informan (berbeda dengan sampel besar pada penelitian kuantitatif untuk kepentingan generalisasi)

Sesuai dengan prinsip penelitian fenomenologis, peneliti harus dapat menggali lebih dalam dengan sumber informasi sebanyak mungkin. Metode ini juga membutuhkan partisipasi peneliti langsung pada subjek di lapangan. Oleh karena itu, peneliti tidak cukup hanya dengan wawancara, tetapi menjadi instrumen kunci dalam penelitian ini. Menurut [18], peneliti mendapat manfaat sebagai instrumen kunci karena sifatnya yang responsif dan mudah beradaptasi. Peneliti sebagai instrumen akan dapat menekankan penekanan holistik, mengembangkan perluasan basis pengetahuan, meniru prosesual, dan memiliki peluang untuk mengklasifikasikan dan meringkas, dan dapat mengambil keuntungan dari peluang untuk menyelidiki respons khusus. Pengumpulan data dalam penelitian ini dilakukan dengan wawancara mendalam, observasi, dan dokumentasi.

\section{Analisis Data}

Penelitian ini mengadopsi analisis data dari Moustakas [20]. Tahap analisis data dalam penelitian ini adalah berikut: 1) mengidentifikasi unit makna dan mengelompokkan tema; 2). individual textural-structural description

3) identifikasi munculnya tema-tema lintas seluruh partisipan (cross participant) atau disebut dengan analisis lintas situs. 4) identifikasi esensi pengalaman. 


\section{Pembahasan}

Penelitian ini merupakan studi investigasi untuk melihat secara lebih dekat melalui pengalaman-pengalaman para informan dalam pengambilan keputusan investasi mereka, terutama dalam perilaku bias overconfidence. Penelitian ini menghasilkan wawancara (in depth interview) dengan 6 informan, yang mewakili seorang day trader, swing trader, position trader, investor berencana, dan investor masa depan [3]. Beberapa studi psikologi telah menunjukkan bahwa kesalahan-kesalahan penilaian terjadi karena orang terlalu percaya diri sehingga dapat memengaruhi keputusan investasi. Investor yang terlalu percaya diri tidak hanya mengambil keputusan salah untuk diri mereka sendiri, tetapi juga menimbulkan efek kuat pada pasar secara keseluruhan. Investor pada umumnya sangat percaya diri. Mereka percaya lebih cerdas daripada orang lain dan mampu memilih saham-saham pemenang, atau memilih manajer keuangan yang lebih cerdas yang dapat mengalahkan pasar, serta memiliki kecenderungan melebih-lebihkan keahlian dan pengetahuan. Berikut adalah refleksi dari hasil wawancara dengan informan yang mengindikasikan tentang perilaku overconfidence mereka.

\section{Overconvidence pada Day Trader}

Day trader adalah trader yang memiliki gaya trading seperti yang dipilih oleh I-5, yaitu mengambil keuntungan dari fluktuasi harga harian. I-5 membuka beberapa posisi dalam sehari. -nya berkisar antara beberapa menit sampai jam per trading. Biasanya beli pagi jual sore. Sifat trader ini sangat spekulatif. Tujuannya murni mencari capital gain. Mereka menggunakan hanya analisis teknikal dalam mengambil keputusan.

Day trader, diprediksi oleh banyak penelitian, adalah trader yang paling sering mengalami overconfidence. Overconvidence sebagai salah satu bias perilaku yang banyak dikaji dalam ranah behavioral finance, adalah keyakinan yang tidak berdasarkan pada intuisi, penyesuaian, ataupun kemampuan kognitif seseorang. Konsep dari overconvidence diturunkan dari eksperimen psikologi kognitif dan survey tempat seseorang overestimate tentang kemampuan prediksinya dan kebenaran informasi yang dipunyai. Seseorang cenderung sulit untuk mengestimasi kemungkinan kejadian yang pasti terjadi, kurang dari 100\%. Artinya orang berpikir bahwa mereka lebih pintar dan memiliki informasi yang lebih baik daripada yang sebenarnya (Pompian, 2006; Daniel et al. dalam Thaler, 2005).

Pada day trader, overconfidence dapat ditunjukkan dengan pola transaksinya yang cenderung overtrading, melakukan trading berkali-kali dalam sehari. Day trader menggunakan alat analisis teknikal yang berupa berbagai grafik pergerakan saham harian secara historis untuk melihat tren. Bahkan, beberapa trader dapat menggunakan sistem robotik untuk memprediksi harga saham ke depan. Teknik ini memungkinkan para trader untuk bertransaksi dalam hitungan menit bahkan detik dengan hanya menebak harga saham akan naik atau turun sehingga lebih mirip taruhan dibandingkan investasi.

Investor overconvidence cenderung untuk melakukan perdagangan yang berlebihan (overtrading) sebagai hasil dari keyakinan bahwa pengetahuan yang dimiliki lebih baik dibandingkan orang lain. Perdagangan yang berlebihan merupakan pendorong dihasilkannya return yang buruk sepanjang waktu. Tentang jumlah trading, I-5 menuturkan bahwa dia dapat melakukan transaksi saham tiga sampai lima kali dalam sehari. Hal ini dilakukan untuk menghindari penyimpanan saham, karena beranggapan hari esok adalah tanpa kepastian sehingga menyimpan saham justru akan menambah risiko.

\section{Overconvidence pada Swing Trader}

Swing Trader adalah seorang yang melakukan trading dalam jangka waktu mingguan. Mereka melakukan trading menyesuaikan dengan goyangan pergerakan harga saham 
mingguan. Overconfidence pada I-4 dan I-6 sebagai swing trader dapat dilihat pada transaksitransaksi mereka yang cenderung melepas saham pemenang lebih cepat untuk mengakumulasi keuntungan, dan cenderung menyimpan saham-saham pecundang dalam jangka panjang. Mereka kurang sabar untuk menunggu saham tersebut mencapai nilai yang sebenarnya. Hal ini sejalan dengan temuan Odean dalam [21] bahwa investor melakukan trading di pasar modal dengan turnover saham yang tinggi, rata-rata $78 \%$, yang berarti bahwa investor itu menjual dan membeli lagi hampir $80 \%$ portofolio mereka. Sebagai tambahan, saham-saham yang dibeli secara konsisten berada di bawah pasar, dan saham yang mereka jual justru mengalahkan pasar.

\section{Overconvidence pada Position Trader}

Position trader adalah trader yang melakukan transaksi bulanan sampai tiga bulanan. Pada penelitian ini diwakili oleh I-2. I-2 adalah seorang pegawai pemerintah yang melakukan transaksi saham. Mengenai overconfidence, demikian penuturan I-2 :

"Cut loss cuma waktu di WTC aja. Yang lain gak pernah. Ya ketika itu saya overconvidence tadi. Setelah sekian lama bu oh saya baru tahu saya overconvidence kemaren. Ya seperti ini buk. Saya kan ngomong. Saya lho sudah investasi sekian lama dan naksir saham ini sekian lama, tapi namanya saham, itu kan ada resiko sistematis, yang overconvidence. Ketika WTC ditabrak itu, saya waktu itu, kejadiannya saya ikut cut loss dan ndak berani masuk, tapi ketika Bom BEJ buk, saya short selling. Ini perilaku lho buk. Ketika saya bom BEJ saya short selling, jadi saya masih mau mengambil keuntungan. Tapi tepat. saya mau keluar atau nge-short, itu karena overconvidence, takut jatuh dan sebagainya. Waktu WTC saya cut loss mestinya kan nge-short". (wc.I2.Aj3.p2)

I-2 menganggap yang dilakukan pada saat terjadintya bom WTC tahun 2001 adalah overconfidence karena panik dan menganggap dirinya paham, muncul perilaku short selling atau cut loss. Short selling adalah melakukan penjualan saham terlebih dahulu meskipun tidak memiliki saham karena yakin adanya penurunan harga yang sangat signifikan di masa depan, kemudian melakukan pembelian saham, hal inilah yang disebut overreaction. Short selling dilarang dalam agama Islam karena menjual barang yang tidak dimiliki saat itu [22]

\section{Overconvidence pada Investor Berencana}

Investor berencana adalah investor yang memasuki pasar modal dan bertransaksi saham karena memiliki pengetahuan dan perencanaan yang matang tentang investasi. Memiliki latar belakang pendidikan tinggi di bidang pasar modal sehingga dapat melakukan analisis dengan benar. Mereka melakukan transaksi saham dalam periode tiga bulan sampai enam bulanan. Overconfidence pada investor berencana sering dimanifestasikan dalam perilaku pembelian saham yang terkesan percaya diri dengan hasil analisisnya sendiri, dan tidak mudah terpengaruh oleh orang lain. Hal ini dapat dilihat pada hasil wawancara berikut.

"Saya seringkali disebut orang, terlalu overconvidence. Nah itu kadangkala yang bisa menilai kan orang lain. Karena orang bilang begini ini (issue), kan belum betul, bapak percaya ini. Tapi semua ini rasional, dan itu menurut pengalaman saya ya buk ya $80 \%$ itu betul. Maka sedikit saya buat agak konservatif pakai estimasi. Saya prediksi sampai (harga saham ASTRA) 48 ribu, malah mencapai 50 ribu, itu tidak berarti overconvidence, tapi buat temen-temen investor, saya menghitung tadi itu kok terlalu percaya diri, saya termasuk yang tidak terlalu suka informasi online, menurut teman-temen, itu terlalu percaya diri karena merasa tidak perlu informasi. Karena saya merasa tahu ilmunya. 
Sekali lagi meskipun tidak $100 \%$ betul, Jadi bagi saya itu yang bisa menilai adalah orang lain, saya dianggap overconvidence. Bagi saya kalau itu betul ya gak juga, gitu ya. Orang dikatakan overconvidence itu bagi saya adalah dia terlalu percaya diri dan dia sering rugi, tapi kalau dia percaya diri dan dia untung, sering untung daripada ruginya, menurut saya itu gak masuk ke sana. Karena prinsip overconvidence adalah orang dikatakan overconvidence jika dia bertransaksi dan sering bertransaksi, ia sering salah. Dia melawan pasar, dia mengagungkan ilmu dia tapi salah, hitungannya salah. Itulah yang namanya menurut saya ya overconvidence. Biasanya ciri khas overconvidence orang itu melakukan apa yang disebut overreaction". (wc.I-1.Ps8.p3).

Bagi I-1, overconfidence adalah seseorang yang sering bertransaksi, tetapi dia sering salah namun, jika seseorang memprediksi dan bertransaksi saham dengan menggunakan analisisnya sendiri dan hasilnya benar, itu bukanlah overconfidence, meskipun banyak teman-temannya mengatakan dia overconfidence, termasuk saat dia lebih menggunakan hasil analisisnya sendiri dibandingkan dengan mendapatkan info dari broker atau orang lain.

\section{Overconvidence pada Investor masa depan}

Investor masa depan adalah investor yang melakukan pembelian saham untuk jangka panjang. Tidak akan melakukan penjualan saham jika tidak diperlukan. Namun investor jangka panjang pun juga akan mengalami overconfidence.

Beberapa studi yang menunjukkan bahwa investor cenderung overconvidence terhadap kemampuan investasi, khususnya investor melakukan prediksi investasi terlalu sederhana. Tipe overconvidence ini disebut prediction overconvidence. Implikasi dari perilaku ini adalah investor akan underestimate terhadap risiko portofolio mereka. Investor juga selalu melakukan penyesuaian dengan terlalu yakin. Hal ini disebut certainty overconvidence. Sebagai contoh, jika investor merasa bahwa sebuah perusahaan merupakan investasi yang bagus, orang cenderung membutakan diri terhadap kemungkinan rugi dan kemudian merasa terkejut dan kecewa jika kinerja investasi menjadi buruk. Seperti hasil wawancara dengan I-3 berikut:

"Saya itu gampang saja, sahamnya aktif diperjual belikan, sahamnya jelas, BUMN lah pasti saya beli. Jelas itu maksudnya kayak Bank BCA, Telkom itu kan jelas, saya milih perusahaan perusahaan yang sudah jelas. Kan secara teori kan kita harus baca laporan keuangannya. Kalau laporan keuangan saya kan bukan seorang akuntan, jadi saya tidak terlalu banyak membaca itu, kalau mungkin anak saya mungkin iya, kalau saya gak. Tapi jelaslah kalau seperti perusahaan-perusahaan gas Negara, secara perasaan ya Bank BCA, memang ya gak boleh main perasaan, tapi ya kasat mata kalau perusahaan ini menguntungkan, ternyata betul juga". (wc.I-3.Ab3.p2)

“Ternyata kalau perusahaan aneh-aneh kayak Fren gini itu malah gak menguntungkan. Atau perusahaan-perusahaan yang berkembang, kadang-kadang murah harganya tapi ya perusahaan berkembang tapi bagus, betul ya nuaiknya, jadi ya dasarnya, meskipun ngerti ya dasarnya, tapi kalau sudah lama berkecimpung di dunia saham ya gak pake lihat laporan keuangan, gak lihat itu. Kita lihat dari perusahaannya ada, gitu aja. Jelas gitu aja. Masa BCA gak jelas, masa Bank Mandiri gak jelas, kan sudah jelas, ya sudah kita pilih. Itu saja dasar saya. Dan ternyata gak salah itu". (wc.I-3.Ab3.p3)

Konsekuensi dari overconvidence adalah Investor yang overconfidence akan overestimate terhadap kemampuannya untuk mengevaluasi perusahaan sebagai investasi yang 
potensial sehingga menjadi buta terhadap informasi negatif yang dalam situasi normal mengindikasikan sinyal peringatan bahwa pembelian saham telah salah atau bahwa saham yang baru saja dibeli harus segera dijual.

Investor overconvidence, karena ketidaktahuan, ketidakmengertian, dan ketidak peduliannya terhadap kinerja investasi historik perusahaan, dapat underestimate terhadap risiko. Akibatnya, muncul portofolio yang tak dapat mengekspektasi kinerja buruk. Investor overconvidence memegang portofolio yang tidak terdiversifikasi dengan baik sehingga cenderung menerima risiko yang lebih dari tingkat toleransi.

Hampir semua investor dan trader pernah mengalami overconvidence, terutama investor yang baru mengenal pasar modal, dan akan semakin berkurang seiring dengan bertambahnya pengalaman bertransaksi. Pada umumnya informan merasakan overconvidence setelah keputusan salah diambil dan mengalami kerugian. Apalagi, ketika terjadi berita buruk, hampir semua informan melakukan overreaction dengan langsung menjual semua saham yang dimiliki tanpa analisis terlebih dahulu. Temuan adanya overconvidence dalam perilaku investor sama dengan temuan dari [23], [24], [25], [8]. Semakin berpengalaman seorang investor, overconfidence semakin berkurang. Emosi yang dipenuhi oleh rasa tamak dan takut yang di awal masuk menjadi investor sangat mendominasi, semakin lama semakin terkontrol, terutama bagi investor yang terus update ilmu pengetahuan dan news akan semakin terkontrol.

Dengan teori pasar efisien, adanya peningkatan jumlah perdagangan selama beberapa tahun terakhir disebabkan investor dan manajer keuangan berkeyakinan memiliki informasi yang lebih baik sehingga DAPAT mendapatkan untung dengan mengelabui investor lain yang merupakan bukti terlalu percaya diri investor [7]. Hasil penelitian Ady \& Mulyaningtyas [26] menunjukkan bahwa pasar modal Indonesia memiliki bentuk pasar efisien bentuk lemah, dengan investor yang masih mendapatkan keuntungan dengan menggunakan data historis.

\section{Kesimpulan}

Overconfidence adalah keyakinan yang tidak berdasarkan pada intuisi, penyesuaian, ataupun kemampuan kognitif seseorang. Overconfidence juga diartikan sebagai kecenderungan pengambil keputusan untuk tanpa disadari memberikan penilaian yang berlebihan terhadap pengetahuan dan keakuratan informasi yang dimiliki dan mengabaikan informasi publik yang tersedia. Akibat overconfidence muncul kecenderungan untuk melakukan perdagangan yang berlebihan (overtrading), overreaction yang berlebihan terhadap suatu kejadian, overestimate terhadap kemampuan untuk mengevaluasi perusahaan sebagai investasi yang potensial sehingga menjadi buta terhadap informasi negative, underestimate terhadap risiko. Akibatnya dapat menghasilkan portofolio yang tak dapat mengekspektasi kinerja buruk. Investor overconvidence memegang portofolio yang tidak terdiversifikasi dengan baik sehingga cenderung menerima risiko yang lebih dari tingkat toleransi. Investor yang overconfidence akan memiliki kecenderungan untuk berperilaku gambling atau judi dan bukan lagi berinvestasi karena tidak melakukan analisis investasi dengan rasional, dan hal ini sangat bertentangan dengan ajaran agama Islam.

Hampir semua investor mengalami overconfidence. Adanya overconfidence pada berbagai jenis trader menunjukkan teknik analisis dan teknologi yang dipakai dalam trading. Day trading sebagai trader dengan time horizon yang paling pendek diantara jenis trader dalam penelitian ini, merupakan trader yang paling beresiko dengan unsur gambling yang tinggi, dan di sisi lain 
perilaku ini justru akan mengakibatkan berkurangnya keuntungan yang dimiliki tanpa disadari oleh investor. Bagi pasar modal secara keseluruhan tingginya overconfidence menyebabkan ketidakstabilan pasar modal. Diperlukan teknologi yang lebih baik dalam analisis pasar modal di masa depan untuk penilaian saham secara lebih akurat untuk menyongsong era industrial 4.0.

\section{References}

[1] I. Keriahenta and N. Sayidah, "Konsep dan Manfaat Pengaturan Saham Tanpa Nilai Nominal dalam Pasar Modal Indonesia,” J. Din. dan Huk., vol. 14, no. 2, pp. 189$199,2014$.

[2] S. U. Ady, "The Moral Values of Psychological Stability, Successful Key of Investment," in 1st International Conference on Intellectuals' Global Responsibility (ICIGR 2017), 2018, vol. 125, no. Icigr 2017, pp. 33-37.

[3] S. U. Ady, M. Sudarma, U. Salim, and S. Aisyah, "Psychology's Factors of Stock Buying and Selling Behavior in Indonesia Stock Exchange (Phenomenology Study of Investor Behavior in Surabaya)," IOSR J. Bus. Manag., vol. 7, no. 3, pp. 11-22, 2013.

[4] M. Ouarda, A. El Bouri, and O. Bernard, "Herding Behavior under Markets Condition: Empirical Evidence on the European Financial Markets,” Int. J. Econ. Financ. Issues, vol. 3, no. 1, pp. 214-228, 2013.

[5] S. Hwang and M. Salmon, "Market stress and herding," J. Empir. Financ., vol. 11, no. 4, pp. 585-616, 2004.

[6] S. U. Ady, Manajemen Psikologi dalam Investasi Saham: Kajian Fenomenologi dalam Sentuhan Behavioral Finance, 1st ed. Jogjakarta: Andi, 2015.

[7] M. M. Pompian, Behavioral Finance and Wealth Management How to Build Optimal Portfolios That Account for Investor Biases, 1st ed. New Jersey: John Wiley \& Sons, 2006.

[8] W. Jannah and S. U. Ady, “Analisis Fundamental, Suku Bunga, Dan Overconfidence Terhadap Pengambilan Keputusan Investasi Pada Investor Di Surabaya,” Ekspektra J. Bisnis dan Manaj., vol. 1, no. 2, pp. 138-155, 2017.

[9] S. U. Ady, "The Cognitive and Psychological Bias in Investment Decision-Making Behavior: (Evidence From Indonesian Investor's Behavior),” J. Econ. Behav. Stud., vol. 10, no. 1, pp. 86-100, 2018.

[10] R. Deaves, E. Lüders, and M. Schröder, "The Dynamics of Overconfidence : Evidence from Stock Market Forecasters The Dynamics of Overconfidence : Stock Market Forecasters," no. 05, 2005.

[11] Nafik H.R.M, Bursa Efek dan Investasi Syari'ah, 1st ed. Jakarta: Serambi, 2009.

[12] J. N. Arthur, R. J. Williams, and P. H. Delfabbro, "The conceptual and empirical relationship between gambling, investing, and speculation,” J. Behav. Addict., vol. 5, no. 4, pp. 580-591, 2016.

[13] R. H. Thaler, Advances in Behavioral Finance: Vol. II, 1st ed. New Jersey: Princeton University Pres, Russell Sage Foundation, 2005.

[14] R. Durand, R. Newby, K. Tant, and S. Trepongkaruna, Overconfidence, overreaction and personality, vol. 5, no. 2. 2013.

[15]J. W. Creswell, Qualitative Inquiry and Research Design: Choosing Among Five Approaches, vol. 2nd ed. 2007.

[16] R. Bogdan and S. K. Biklen, Qualitative Reseach for Education: an Introduction to theory and Method, 4th ed. Boston: Pearson, 2003. 
[17]B. G. Glaser and A. L. Strauss, The Discovery of Grounded Theory: Strategies for Qualitative Research, vol. 1, no. 4. 1967.

[18] E. G. Guba and Y. S. Lincoln, "Competing paradigms in qualitative research," Approaches to qualitative research: A reader on theory and practice. pp. 17-38, 2004.

[19] E. G. Guba and Y. S. Lincoln, "Competing Paradigms in Qualitative Research," Handb. Qual. Res., pp. 105-117, 1994.

[20] C. E. Moustakas, Phenomenological Research Methods, 1st ed. USA: Sage Publications, Inc, 1994.

[21] N. Barberis and R. Thaler, "a Survey of Behavioral Finance ${ }^{\circ}$," in Handbook of the Economics of Finance, M. H. and R. S. G.M. Constantinides, Ed. Chicago, 2003, p. 71.

[22] M. Nafik HR, Bursa Efek dan Investasi Syariah, 1st ed. Jakarta: PT. Serambi Ilmu Semesta, 2009.

[23] W. F. M. De Bondt, “A Portrait of Individual Investor,” Eoropean Econ. Rev., vol. 42, pp. 831-844, 1998.

[24] W. K. Campbell, A. S. Goodie, and J. D. Foster, "Narcissism , Confidence , and Risk Attitude," J. Behav. Decis. Mak., vol. 17, pp. 297-311, 2004.

[25] J. F. Yates, Judgment and Decision Making. Englewood Cliffs, NJ: Prentice Hall. Prentice Hall, 1991.

[26] S. U. Ady and A. Mulyaningtyas, "Eksplorasi Tingkat Efisiensi Pasar Modal Indonesia, Studi Kasus di Bursa Efek Indonesia," Ekspektra J. Bisnis dan Manaj., vol. 1, no. 2, pp. 103-123, 2017. 